\title{
PHP2D OLAHAN LIMBAH TEMBAKAU DAN RAMBUT JAGUNG BAGI WARGA DESA BANYULEGI, KECAMATAN DAWARBLANDONG, MOJOKERTO
}

\author{
Sahroni ${ }^{1}$, Dyah Puspita Indah Budi Sari Wulan ${ }^{2}$, Mazitdatur Rohmah ${ }^{3}$, Niken Ayu Aprilia ${ }^{4}$, Adellia \\ Putriani $^{5}$, Faisol Humaidi ${ }^{6}$. \\ 1,2,3,4,5,6 Universitas Wijaya Putra \\ sah810534@gmail.com
}

\begin{abstract}
Abstrak
Latar belakang program PHP2D (Program Holistik Pembinaan Dan Pemberdayaan Desa) pada kelompok tani Desa Banyulegi, Kecamatan Dawarblandong, Mojokerto adalah adanya perbedaan potensi hasil pertanian antara musim kemarau dan musim penghujan. Pada musim kemarau kelompok tani / GAPOKTAN dibuat kewalahan dengan serangan hama yang menyerang tanaman seperti tanaman jagung, tembakau, kangkung dll. Serangan hama tersebut menyebabkan penurunan produksi tanaman budidaya serta limbah tanaman tersebut yang tidak terpakai. Sedangkan tujuan dari PHP2D memanfaatkan limbah daun tembakau sebagai insektisida alami (Botanical Insecticide) untuk pengendalian hama pada tanaman jagung dan padi, serta memanfaatkan limbah rambut jagung sebagai olahan minuman yang baik dikonsumsi untuk kesehatan. Metode yang digunakan mengolah limbah daun tembakau menjadi insektisida organik berbasis lingkungan serta mengolah limbah rambut jagung menjadi teh yang berguna untuk kesehatan. Hasil kegiatan PHP2D adalah kelompok tani/ GAPOKTAN Banyulegi mahir membuat insektisida organik berbasis lingkungan, juga kelompok ibu- ibu PKK mahir membuat teh rambut jagung yang siap dipasarkan kekonsumen. Disamping itu, dapat meningkatkan pendapatan kelompok tani dan ibuibu PKK Desa Banyulegi sampai akhir Agustus 2020 didapatkan penghasilan tambahan untuk kelompok tani dalam 1 bulan sebesar Rp. 1. 250.000,00 Sedangkan untuk penghasilan ibu- ibu PKK dalam 1 bulan sebesar Rp. $750.000,00$.
\end{abstract}

Kata kunci : PHP2D, daun tembakau, rambut jagung, GAPOKTAN

\section{PENDAHULUAN}

Desa Banyulegi merupakan salah satu desa yang terletak di Kecamatan Dawarblandong Kabupaten Mojokerto terbagi menjadi 4 dusun yaitu dusun Glagah, dusun Ngarus, dusun Balong dan dusun Banyulegi. Mayoritas potensi tiap dusun adalah pertanian termasuk salah satunya Dusun Glagah. Dusun Glagah terdiri dari 6 RT dan 3 RW dengan jumlah keseluruhan 185 kepala keluarga (https://id.wikipedia.org/, 20200
Berdasarkan hasil observasi dan wawancara yang dilakukan oleh tim, Pak Supriyanto selaku Kepala Dusun Glagah, terdapat perbedaan potensi hasil pertanian antara musim kemarau dan musim penghujan. Pada musim kemarau, mayoritas penduduk merupakan petani tembakau dan sisanya petani kangkung dan jagung. Pada musim penghujan, mayoritas penduduk beralih menjadi petani padi. Selain itu, pak Supriyanto mengatakan dalam dua tahun ini petani dibuat kewalahan dengan serangan hama terutama dalam penanaman padi

$$
\text { Teknologi Tepat Guna }
$$


dimusim penghujan. Hama tersebut adalah ulat daun dan tikus. Sehingga berdampak pada jumlah panen dan keresahan warga setempat.

Tabel 1. Data Luas Pertanaman Tembakau dan Jagung di Desa Banyulegi 2017-2018

\begin{tabular}{ccccc}
\hline Tahun & $\begin{array}{c}\text { Jenis } \\
\text { Panen }\end{array}$ & $\begin{array}{c}\text { Luas } \\
\text { Panen } \\
(\mathrm{Ha})\end{array}$ & $\begin{array}{c}\text { Rata-rata } \\
\text { Produksi } \\
(\mathrm{Ku} / \mathrm{Ha})\end{array}$ & $\begin{array}{c}\text { Produksi } \\
\text { (ton) }\end{array}$ \\
\hline \multirow{2}{*}{2018} & Tembakau & 42,00 & 94,50 & 377,75 \\
\cline { 2 - 5 } 2017 & Jagung & 44,00 & 46,00 & 202,40 \\
\cline { 2 - 5 } & Tembakau & 38 & 98,50 & 374,30 \\
\hline
\end{tabular}

Sumber : Kecamatan Dawar Blandong Dalam Angka 2019,

Berdasarkan tabel 1 diatas, luas panen jagung di desa Banyulegi pada tahun 2018 adalah sebesar 44 Hektar dengan total panen jagung sebesar 202,40 ton. Jumlah ini sangat kecil jika dibandingkan total panen jagung pada tahun 2017 sebesar 519,80 tin. Penduduk masyarakat desa Banyulegi utamanya dusun glagah, mengolah jagung hasil panen dengan cara dislap kemudian dijual untuk bahan makanan burung. Proses slap produk samping berupa limbah rambut jagung. Limbah tersebut dibuang secara percuma tanpa melalui proses pemanfaatan terlebih dahulu. Disamping itu, luas panen tembakau di desa Banyulegi pada tahun 2018 adalah 42 Hektar dengan total panen tembakau sebesar 377,75 ton. Jumlah ini menandakan panen tembakau mengalami peningkatan dibandingkan tahun 2017 sebesar 374,30 ton walaupun tidak signifikan. Tembakau yang siap panen dijual kepada pabrik pembuat rokok, hasil samping panen tembakau juga menghasilkan produk samping berupa limbah daun yang cacat dan tangkai tembakau yang biasanya dikumpulkan kemudian dijual seharga 5.000/kg. Namun, mayoritas masyarakat membiarkan limbah tersebut menumpuk dilahan mereka sehingga menimbulkan pencemaran.

Di dusun Glagah terdapat kelompok masyarakat khusus petani dinamakan Gabungan Kelompok Tani (GAPOKTAN), berfungsi seperti halnya koperasi penyedia bibit dan pupuk serta keperluan tanam para petani di desa Banyulegi. Terjadinya penurunan produktivitas lahan pertanian diiringi dengan rendahnya produktivitas petani. Terlebih lagi pada kondisi pandemi covid-19 yang menyebabkan perputaran ekonomi melemah dan berakibat pada rendahnya tingkat pendapatan penduduk yang bekerja.

Berdasarkan permasalahan diatas, perlu adanya suatu pengelolaan dan inovasi yang bertujuan untuk memberikan nilai tambah pada rambut jagung dan limbah tembakau. Oleh karena itu, perlu adanya program pemberdayaan masyarakat karena kesadaran dan peran serta keaktifan masyarakat sangat diperlukan. Untuk menjaga kesinambungan program, maka perlu dibentuknya komunitas. Melalui Program Holistik Pemberdayaan dan Pembinaan Desa di Desa Banyulegi, Kecamatan Dawarblandong Kabupaten Mojokerto dibentuk program "OMA AGUNG". Solusi tersebut diharapkan mampu meningkatkan produktivitas gabungan kelompok tani dan perekonomian warga Desa Banyulegi Kecamatan Dawarblandong Kabupaten Mojokerto utamanya di masa pandemi covid-19

\section{METODE}

1. Metode Pemberdayaan Masyarakat Desa

Pemberdayaan masyarakat desa dilaksanakan secara Offline (Kegiatan di Lapangan) dan online. Pemillihan metode ini dikarenakan wilayah desa Banyulegi merupakan wilayah zona kuning covid-19 dengan jumlah odp sebanyak 2 orang sehingga perlu adanya pelaksanaan pemberdayaan dalam metode online sebagai upaya memutus mata rantai penularan covid-19 mengingat peneliti seluruhnya berasal dari zona merah covid-19.

2. Metode Pelaksanaan Kegiatan

a. Pemberdayaan limbah daun tembakau.

Langkah awal dengan menyiapkan bahan baku limbah daun tembakau dan alat untuk pembuatan insektisida organik seperti, tangki 250 liter dan tong 50 liter, limbah daun tembakau 100 gram, alcohol 70\% 100 $\mathrm{ml}$, serta air 10 liter. Siapkan bak penampung dengan dimasukkan limbah daun tembakau 100 gram serta alcohol $70 \%$ sebanyak $100 \mathrm{ml}$, lalu dicampurkan 9,8 liter air, kemudian bak penampung ditutup rapat dengan plastik serta didiamkan selama 48 jam. Setelah 48 jam kemudian, penutup bak penampung dibuka. Langkah selanjutnya cairan insektisida organic disaring dan

Teknologi Tepat Guna

200 
dimasukkan kedalam botol plastic kemasan berukuran $1000 \mathrm{ml}$.

b. Pemberdayaan limbah rambut jagung Langkah awal dengan menyiapkan bahan baku limbah rambut jagung dan alat untuk pembuatan teh rambut jagung seperti, limbah rambut jagung 100 gram, air, kertas roti, kantong teh, standing pouch, oven gas $120 \times 55 \times 70 \mathrm{~cm}+$ Loyang, alat pres, timba 10 liter, serta timbangan. Pertama, menyiapkan limbah rambut jagung lalu dimasukkan kedalam bak/ timba, kemudian bersihkan dengan menggunakan air yang jernih, setelah itu menyiapkan rambut jagung yang sudah dibersihkan. Setelah itu, memanaskan oven kemudian memasukkan rambut jagung yang diletakkan diloyang yang dilapisi kertas roti selama 7 menit didalam oven. Setelah dioven, timbang rambut jagung dengan takaran 2 gram kemudian dimasukkan kedalam kantong teh yang telah disiapkan dan dipres menggunakan alat pres untuk menutup kantong teh.

3. Monitoring dan Evaluasi Program Evaluasi dilaksanakan untuk mengetahui kekurangan dalam pelaksanaan program. Melalui proses evaluasi, kekurangan yang terjadi dalam pelaksanaan program dapat dijadikan langkah perbaikan untuk kedepannya.

Monitoring dilaksanakan sebagai upaya pengendalian jalannya program OMA AGUNG dari proses produksi hingga pemasaran serta melakukan bimbingan terhadap Tim Pengelola OMA AGUNG untuk menjaga keberlanjutan program OMA AGUNG

\section{HASIL DAN PEMBAHASAN}

\section{Introduksi Teknologi Pembuatan Pestisida Organik (Insidius)}

Pemberdayaan masyarakat yang dilaksanakan oleh tim UKKI Universitas Wijaya Putra di desa Banyulegi, Kecamatan DawarBlandong, Mojokerto dengan introduksi pembuatan insektisida organik dari limbah daun tembakau. Kelompok tani Banyulegi yang mengikuti pemberdayaan sebanayak
10 petani. Dari hasil analisis respon introduksi paket teknologi diperoleh hasil sebagai berikut :

Tabel 1 Prosentase tingkat Pemahaman Petani dalam Pembuatan Isektisida Organik

\begin{tabular}{lrr}
\hline & Jumlah Petani & \% PAHAM \\
\hline Pre test & 10 & 20 \\
\hline Post test & 10 & 80 \\
\hline
\end{tabular}

Dari 10 petani yang mengikuti introduksi pembuatan insektisida organik sebanayak $80 \%$ paham dan bersedia membuat insektisida organic untuk diaplikasikan ke lahan mereka dalam mengendalikan hama pada tanaman budidaya. Dan sebanyak $20 \%$ (2 orang) masih belum paham dalam pembuatan insektisida organik dari limbah tembakau.

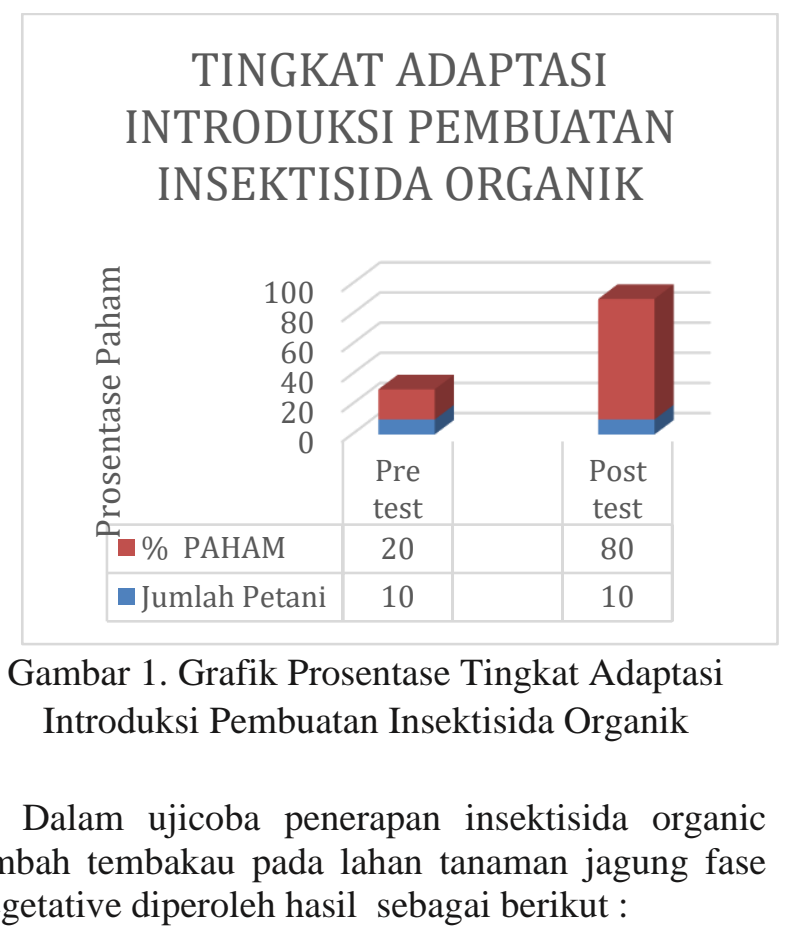


Tabel 2. Tingkat Mortalitas Hama Tanaman Jagung Akibat Pemberian Insektisida Organik.

\begin{tabular}{|c|c|c|c|}
\hline No & $\begin{array}{l}\text { Jenis } \\
\text { Tanaman }\end{array}$ & Jenis Hama & $\%$ Mortalitas \\
\hline \multirow[t]{4}{*}{1} & \multirow[t]{4}{*}{ Jagung } & $\begin{array}{l}\text { 1. Spodoptera } \\
\text { frugiperda } \\
\text { (ulat grayak) }\end{array}$ & $67 \%$ \\
\hline & & $\begin{array}{ll}\text { 2. } & \begin{array}{l}\text { Aphis spp } \\
\text { (kutu daun) }\end{array} \\
\end{array}$ & $76 \%$ \\
\hline & & $\begin{array}{l}\text { 3. } \begin{array}{l}\text { Planococus } \\
\text { citri (kutu } \\
\text { putih) }\end{array} \\
\end{array}$ & $77 \%$ \\
\hline & & $\begin{array}{ll}\text { 4. } & \text { Heliothis } \\
\text { armigera } \\
\text { (penggerek } \\
\text { tongkol) }\end{array}$ & $65 \%$ \\
\hline
\end{tabular}

Tingkat kematian /mortalitas hama-hama pada tanaman jagung berkisar $65 \%$ s/d $77 \%$ yang efektif menekan hama dari golongan ulat dank utu daun. Maka insektisida organic tersebut layak dikembangkan secara komersial bagi kelompok tani desa Banyulegi Kecamatan DawarBlandong, Mojokerto. Dari HPP Insektisida organic daun tembakau per 1 liter seharga Rp.25.000. Sampai akhir Agustus 2020 penjualan insektisida organic didapatkan penghasilan kotor untuk kelompok tani dalam 1 bulan sebesar Rp. 1. 250.000,

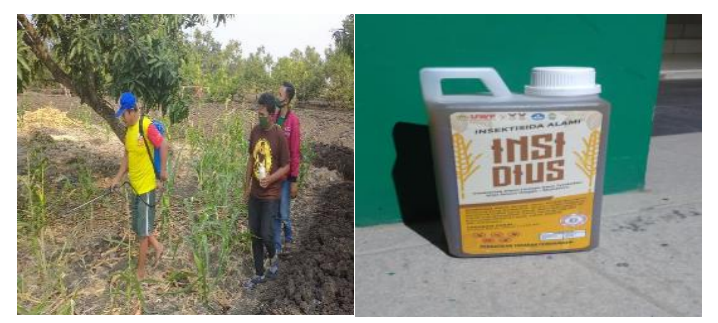

Gambar 2. Ujicoba Penerapan Insektisida Organik

\section{Introduksi Teknologi Pembuatan Teh Rambut Jagung (Oma Agung)}

Dalam pemberdayaan petani untuk pembuatan teh rambut jagung di desa Banyulegi, Kecamatan Dawarblandong, Mojokerto yang dilakukan oleh ibu-ibu petani dalam rangka peningkatan produktifitas ekonomi kerakyatan. Teh rambut jagung yang diintroduksi sebanyak 6 orang. Dari ke enam ibu-ibu petani sebagian besar paham dan mengerti dalam proses pembuatan teh rambut jagung.

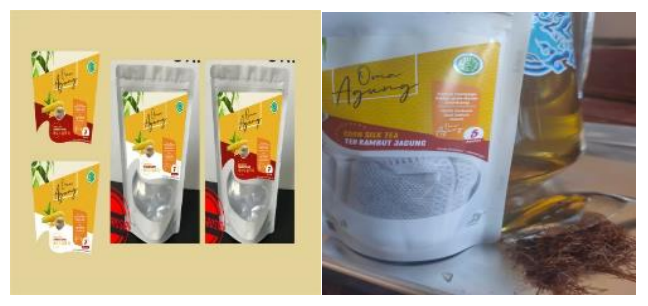

Gambar 3. Kemasan Teh Rambut Jagung

Khasiat dari teh rambut jagung untuk meningkatkan peredaran darah dan peningkatan kesehatan tubuh manusia. Harga per kemasan sebesar Rp.7.500. Sedangkan untuk penghasilan ibuibu PKK dalam 1 bulan sebesar Rp. 750.000,00.

\section{KESIMPULAN}

Dari kegiatan PHP2D di desa Banyulegi, Kecamatan Dawarblandong, Mojokerto didapatkan kesimpulan sebagai berikut :

1. Tingkat pemahaman introduksi teknologi pembuatan insektisida organik pada kelompok tani sebesar 80\%, sedangkan tingkat pemahaman pembuatan teh rambut jagung bagi ibu-ubu petani/PKK sebesar $100 \%$.

2. Efektifitas pengendalian hama pada tanaman jagung berkisar $65 \%$ s/d 77\%.

3. Introduksi pembuatan Teh rambut jagung dapat meningkatkan pendapatan kelompok PKK desa Banyulegi.

$$
\text { Teknologi Tepat Guna }
$$


4. Dari penjualan insektisida organik dapat meningkatkan pendapatan kelompok tani desa Banyulegi, Kecamatan Dawarblandong, Mojokerto

Adapun rekomendasi dari PHP2D bagi masyarakat desa Banyulegi, Kecamatan Dawarblanding, Mojokerto adalah, dalam kegiatan pembuatan insektisida alami dapat dikerjakan kelompok tani, sedangkan pembuatan teh rambut jagung dilakukan oleh ibu-ibu PKK. Kedua roduk tersebut dapat bekerja sama dengan BUMDES dalam pemasaran produk tersebut.

\section{UCAPAN TERIMAKASIH}

1. Tim PHP2D UWP mengucapkan terima kasih kepada kelompok tani Desa Banyulegi, Kecamatan Dawarblandong, Mojokerto yang telah menerima dan bersedia mengikuti pemberdayaan dan pelatihan oleh Tim PHP2D UWP.

2. Tim PHP2D UWP mengucapkan terima kasih kepada Universitas Wijaya Putra yang telah banyak mendukung dan memfasilitasi program PHP2D

3. Tim PHP2D UWP mengucapkan terima kasih kepada Direktorat Pembelajaran dan Kemahasiswaan Dikti yang telah membiayai kegiatan PHP2D tahun anggaran 2020.

\section{REFERENSI}

BPS Kabupaten Mojokerto, 2019, Kecamatan Dawar Blandong DalamAngka 2019, https://mojokertokab.bps.go.id/publication/ 2019/09/26/d77307fb30c76b3cd24b0ffa/kec amatan-dawar-blandong-dalamangka2019.html

Anonimous, 2020, Profil Desa Banyulegi Kecamatan Dawarblandong,Mojokerto,https://id.wikipe dia.org/wiki/Banyulegi,_Dawarblandong,_ Mojokerto 